\title{
Examination of Physical and Physiological Parameters of National Level Boxers at Age Range of 11-13
}

\author{
Aziz Güçlüöver ${ }^{1}$, Melike Taşbilek Yoncalık ${ }^{1}$, Hüseyin Fatih Şen ${ }^{2} \&$ İrem Nur Şahin ${ }^{3}$ \\ ${ }^{1}$ Kırıkkale University, Faculty of Sport Sciences, Kırıkkale, Turkey \\ ${ }^{2}$ Selçuk University, Health Sciences Institute, Konya, Turkey \\ ${ }^{3}$ Hitit University, Health Sciences Institute, Çorum, Turkey \\ Correspondence: Aziz Güçlüöver, Kırıkkale University, Faculty of Sport Sciences, Physical Educationand Sports \\ Teaching Department, Kırıkkale, Turkey. E-mail: azizgucluover@hotmail.com
}

Received: August 17, 2019

Accepted: September 10, 2019

Online Published: September 20, 2019

doi:10.5539/jel.v8n5p185

URL: https://doi.org/10.5539/jel.v8n5p185

\begin{abstract}
Delivering successful performance in sports depends on physical fitness. Unless the physical and physiological structure is in accordance with the requirements of the sports branch, a high performance in sports cannot be realized fully (Çakmakçı, 2002). Therefore, it is important to define and improve performance parameters such as body composition, anaerobic-aerobic endurance, capacity and strength in boxing. Accordingly, In this study, it is aimed to examine the physical and physiological fitness parameters of tiny natioanal boxers between 11-13 years of age. The research was carried out on 12 boxing athletes between 11-13 years of age in the tiny national category in Kirıkkale province. In statistical analysis, normality was understood by Shapiro-Wilk test and descriptive statistics method was used to define the data. In this study, maximum oxygen consumption capacity (VO2) maxs, lung functional volumes, hand grip strength levels and body composition measurements of boxing athletes were evaluated. The mean of (VO2) max values of the participants were measured $44.17 \pm 8.45$. Also in correlation analysis, a high relationship was found at (VO2) max BMR; $r=-750, p=0.01$ level between maximal oxygen consumption capacity and basal metabolic rate However, in oxygen consumption capacity and body composition variables, The negatively significant level relationships were found at levels of (VO2) max; body fat percentage (FM), $r=-696, p=0.05$, lean body mass (FFM), $r=-666, p=0.05$; body mass index (BMI), $r=-763, p=0.01)$. As a result, in this study, identification and relationship were determined about performance data in physical and physiological fitness parameters of tiny elite boxing athletes and a data about this age group was created in boxing athletes for future studies.
\end{abstract}

Keywords: aerobic exercise, squeezing force, athletes, national

\section{Introduction}

Achieving a high level of performance in sport results from a combination of many factors. The most important of these is physical fitness. Physical fitness is the most important criterion in determining the physiological capacity (Çakmakçi et al., 2018; Tatlici et al., 2018). In order for the sportive performance to be at high efficiency, the physical and physiological structure specific to the sport branch must be suitable (Kalyon, 1990; Özer \& Kılınç, 2011). Each sports branch for high performance; requires to some physiological characteristics that should be more dominant according to intensity, frequency, duration, intensity, movement variety and the muscle groups used (Selçuk, 2014). In addition to these physiological features, the athlete has to perfect these features through exercises (Tatlic1 et al., 2018). The main purpose of the exercise; is to regulate the distribution of oxygen, to put the metabolic processes in the way, develop strength, endurance and improve muscle-joint movements (Tayar \& Korkmaz, 2007). In this way, the physical and physiological structure of the athlete becomes more suitable for the conditions required by the branch and the fighting power is increased. As boxing requires high physical capacity and skill, boxing athlete must have many physical, motoric and biochemical factors together (Kılıç, 2012; Soslu et al., 2018; Tatlici \& Çakmakci, 2019). The general strength required for boxing consists of a combination of strength, speed, muscular and respiratory-circulatory system resistance (Çakmakci et al., 2019). Endurance is highly dependent on the aerobic capacity of the athlete and less on the anaerobic capacity (Soslu et al., 2019). Durability in the application of technical movements; is provided by reinforcing special sporting abilities (Karatosun, 2003). As to considering the muscle group and the variety of 
movement of the boxing branch, the importance of the upper extremities increases and the training focuses more on this region (Selçuk, 2014). Aerobic capacity; defined as the amount of maximal oxygen consumed per minute during maximal exercise. High aerobic capacity can be positively transferred to anaerobic capacity. If an athlete develops aerobic capacity, anaerobic capacity will also improve. Because the athlete will be able to function for a long time without entering the oxygen debt, and will recover in a very short time after entering the oxygen debt (Sevim, 1991). Boxing is a sport where sudden combined strokes are performed and therefore energy loss is at a high level. In this respect, the importance of maximal strength and anaerobic power in boxing is understood (Selçuk, 2014). Strength, which is one of the basic conditions for demonstrating a movement in sports (Tatlici \& Unlu, 2018), increases or is maintained depending on the developments in muscles with various exercises (Soslu et al., 2018). The rationale for measuring force can be categorized into two areas, anatomical and physiological. Measurement of hand grip strength is an example of isometric muscle movement or static exercise (William \& Gene, 2013). Strength and muscular endurance are measured by dynamometers, cable tensiometers, electromechanical devices, invariant resistances and variable resistant exercise machines (Özer, 2016). Differences in age of athletes, hand grip strength and fat percentage are also among the main reasons that affect success in boxing. It is thought that Turkish athletes will be developed as a result of comparison with the boxers of the countries which are good in terms of success in order to be more successful (Çınar, Biçer, Pala, \& Savucu, 2009). Bone structure is a lifelong active structure and their development varies (Bozkurt, 2010). The muscles and bone structure of one of the two athletes who are at the same height and weight may be more developed than the other and more success can be obtained (Bozkurt, 2010; Bozkurt, 2011). In this case, The body fat percentage of the one whose muscle and bone structure have been undeveloped will be higher and appearance will be fatter than the other. The ideal weight varies according to gender and height in adults and age and gender in children (Zorba, 2001). BMI (Body Mass Index) is one of the simplest measures in determining ideal weight. According to this; $\mathrm{BMI}=$ is calculated as Weight $(\mathrm{kg}) / \mathrm{Height}^{2}\left(\mathrm{~m}^{2}\right)($ Zorba, 2014).

Lung volume measurement during resting increases the rate of interpretation of lung volumes during exercise. The most important test in measuring the maximal aerobic strength of the athlete is the maximal oxygen consumption (max.VO2) test, which depends on the age, gender and body composition of the athlete (Tamer, 2000). It exudes three out of 4 components of the total lung volume while performing the vital capacity test. These; breathing reserve volume (NRV = BRV), tidal volum $(\mathrm{TV})$ and expiratory reserve volume (ERV). Although it does not measure the overall lung capacity, it provides an indirect measure of lung capacity (William \& Gene, 2013). Success in sports can be achieved by combining many complementary features, such as the rings of the chain. Boxing also has a structure that requires a combination of many features such as technique, tactic, durability, quickness and coordination. In addition to the completion of all these features, success in boxing will be possible with the increase of scientific research, development of general training programs, selection of talented and suitable athletes for physical characteristics, and teaching of technical and tactical studies with different methods (Aydaş et al., 2002). In this context, in the research, the physical and physiological fitness levels of the young level national boxing athletes who are at the 11-13 age were determined,. in line with these results, identification and due diligence regarding the performances of athletes were made and data for this age group were presented in the literature.

\section{Method}

\subsection{Sample}

The aim of this study was to investigate the physical and physiological fitness parameters of the tiny national boxers who are at the age of 11-13. The sample of the study constitutes 12 national athletes in the range of 1113 years of age from Kırkkale Provincial Directorate of Youth and Sports boxing club depending Turkey Boxing Federation.

\subsection{Procedure}

The design of the research was realized with the descriptive-relational survey model which is one of the quantitative research methods.

\subsection{Data Collection}

Before the participation in the tests, written permission was obtained from the athletes and their families (voluntary consent form). Within the scope of the study, all measurements were performed in the Physiology and Performance Laboratory of Faculty of Education of Kirlkkale University. Before the tests, the necessarry information was given to the athletes and the adaption to the tests was provded. The length and body weight values of the participants were taken firstly. The measurements of Pulmonary functions (FVC, FEV1, FEV1/FVC and VC) were performed by Cosmed brand 'Spirometry USA Device'. Disposable apparatuses were 
used for vital capacity measurements. The athletes were shown the protocol in accordance with the measuring principle of the device and they were performed trails. In the laboratory, students were asked to sit on the chair and blow into the device and the best value was recorded after three measurements. The (VO2) $\max$ measurements of the athletes (VO2) were carried out directly gas analyzer device marked Cosmed fitmate PRO USA. After calibrating the device, entering gender, age, height and weight values, the test mask was worn in the shape of taking nose and mouth in and no air leakage. The Bruce test protocol was applied on the treadmill for approximately 15 minutes. The test is based on the stress test of cardiac performance with sub-maximal loading by incrementally increasing treadmill speed and inclination every three minutes (Williams \& Wilkins, 2013). As a result of the test obtained from the device, the amount of ventilation (breath), oxygen consumption (VO2), average breath frequency, pulse rate (HR), $\mathrm{FeO} 2$ average oxygen density, loading amount, energy consumption and the steps of the test can be seen at the intervals of 15 seconds.

Table 1. Bruce protokol

\begin{tabular}{llll}
\hline Stage & Speed $(\mathbf{k m} / \mathbf{s})$ & Speed(mph) & Slope \\
\hline 1 & 2.74 & 1.7 & 10 \\
2 & 4.02 & 2.5 & 12 \\
3 & 5.47 & 3.4 & 14 \\
4 & 6.76 & 4.2 & 16 \\
5 & 8.05 & 5.0 & 18 \\
6 & 8.85 & 5.5 & 20 \\
7 & 9.65 & 6.0 & 22 \\
8 & 10.46 & 6.5 & 24 \\
9 & 11.26 & 7.0 & 26 \\
10 & 12.07 & 7.5 & 28 \\
\hline
\end{tabular}

Note. ACSM's health-related physical fitness assessment manual (2013).

The bioelectrical impedance analyzer device marked Tanita Body Composition Analyzer BC-418 was used to determine the body composition of the athletes. The device analyzes the fat and lean body weight by sending a $50 \mathrm{kHz}$ electrical current to the body parts. the Haris-Benedict formula was used for the basal metabolic rate measurement in tiny boxing athletes.

In addition, Haris-Benedict formula was used for basal metabolic speed measurement in young-level boxing athletes.

BMR $($ Male $)=66.473+(13.752 \times$ Weight $)+(5.003 \times$ Height $)-(6.755 \times$ Age $)$

\subsection{Data Analyses}

In this research, SPSS 18 package program was used for data analysis. The age, anthropometric measurements (height, weight), body composition values, lung functional volume values, hand grip strength, the definition of minimum, maximum, arithmetic mean and standard deviation data beleging to (VO2) max values and basal metabolism rate (BMR) of the boxing athletes participating in the study was calculated by the descriptive statistical method. Pearson correlation coefficient was used to determine the correlation relationships between physical and physiological variables of athletes.

\section{Results}

As a result of descriptive statistical analyzes in the research, the mean values of the data of the tiny national boxers respectively found to be; age, $12.33 \pm 7$, height, $152.3 \pm 7.8$, weight; $44.5 \pm 7.3$, (VO2) max; $44.17 \pm 8.4$, fat percentage, $17.8 \pm 1.1$, lean body mass, $36.0 \pm 4.6$, body mass index, $18.9 \pm 2.2$, right hand grip strength, 24.8 \pm 4.1 , left hand grip strength was $26.3 \pm 4.1, \mathrm{FEV} 1 / \mathrm{FVC} \%, 107.5 \pm 4.9, \mathrm{FEV} 1 \%, 91.3 \pm 8.9, \mathrm{VC} \%, 100.1 \pm 9.9$, $\mathrm{FVC} \%, 85.1 \pm 9.9 \%$ (Table 2). In case of correlation analysis, a high correlation was found between maximal oxygen consumption capacity and basal metabolic rate at level of ((VO2) max, BMR; $r=-750, p=0.01$ ) (Table $3)$. However, The negatively relationships at significant were determined between oxygen consumption capacity and body composition variables (VO2) max; body fat percentage at the level of (FM), $r=-696, p=0.05$, lean body mass (FFM), $\mathrm{r}=-666, \mathrm{p}=0.05$; body mass index (BMI), $\mathrm{r}=-763, \mathrm{p}=0.01)$ (Table 4). 
Table 2. Descriptive statistics of physical-physiological data of national tiny boxers

\begin{tabular}{llllll}
\hline Variables & $\mathbf{N}$ & min & max & Mean & sd. \\
\hline Age & 12 & 11.00 & 13.00 & 12.33 & .77 \\
Height & 12 & 143.00 & 162.00 & 152.33 & 7.83 \\
Weight & 12 & 36.70 & 55.45 & 44.58 & 7.39 \\
$\left(\mathrm{VO}_{2}\right)_{\max } \mathrm{ml} / \mathrm{kg} / \mathrm{min}$ & 12 & 35.00 & 49.20 & 44.17 & 8.45 \\
Fat Percentage (FM) & 12 & 16.28 & 18.43 & 17.80 & 1.15 \\
Lean Body (FFM) & 12 & 31.40 & 43.00 & 36.00 & 4.63 \\
BMI(BKI) & 12 & 16.00 & 22.30 & 18.93 & 2.27 \\
Right hand grip (kg) & 12 & 21.00 & 31.00 & 24.83 & 4.10 \\
Left hand grip (kg) & 12 & 22.00 & 33.00 & 26.33 & 4.11 \\
FEV1/FVC \% & 12 & 101.00 & 114.00 & 107.50 & 4.92 \\
FEV1 \% & 12 & 79.00 & 99.00 & 91.33 & 8.99 \\
VC \% & 12 & 85.00 & 113.00 & 100.16 & 9.97 \\
FVC \% & 12 & 69.00 & 98.00 & 85.16 & 9.95 \\
BMR (kcal) & 12 & 1214.75 & 1538.71 & 1358.66 & 131.86 \\
\hline
\end{tabular}

Table 3. Correlation relationships between respiratory functions and oxygen consumption capacities and basal metabolic rate variables of tiny national boxers

\begin{tabular}{llllllll}
\hline & & $\left(\mathrm{VO}_{2}\right)_{\max }$ & $\mathrm{FEV}_{1} / \mathrm{FVC}$ & $\mathrm{FEV}_{1}$ & $\mathrm{VC}$ & $\mathrm{FVC}$ & $\mathrm{BMR}$ \\
\hline$\left(\mathrm{VO}_{2}\right)_{\max }$ & $\mathrm{r}$ & - & -.248 & .344 & .313 & .361 & $-.750^{* *}$ \\
& $\mathrm{p}$ & - & .437 & .274 & .321 & .250 & .005 \\
& $\mathrm{n}$ & - & 12 & 12 & 12 & 12 & 12 \\
$\mathrm{FEV}_{1} / \mathrm{FVC}$ & $\mathrm{r}$ & -.248 & - & -.221 & $-.601^{*}$ & $-.580^{*}$ & .301 \\
& $\mathrm{p}$ & .437 & - & .489 & .039 & .048 & .343 \\
& $\mathrm{n}$ & 12 & - & 12 & 12 & 12 & 12 \\
$\mathrm{FEV}_{1}$ & $\mathrm{r}$ & .344 & -.221 & - & $.897^{* *}$ & $.921^{* *}$ & $-.618^{*}$ \\
& $\mathrm{p}$ & .274 & .489 & - & .000 & .000 & .032 \\
& $\mathrm{n}$ & 12 & 12 & - & 12 & 12 & 12 \\
$\mathrm{VC}$ & $\mathrm{r}$ & .313 & $-.601^{*}$ & $.897^{* *}$ & - & $.991^{* *}$ & -.526 \\
& $\mathrm{p}$ & .321 & .039 & .000 & - & .000 & .079 \\
& $\mathrm{n}$ & 12 & 12 & 12 & - & 12 & 12 \\
$\mathrm{FVC}$ & $\mathrm{r}$ & .361 & $-.580^{*}$ & $.921^{* *}$ & $.991^{* *}$ & - & $-.616^{*}$ \\
& $\mathrm{p}$ & .250 & .048 & .000 & .000 & - & .033 \\
& $\mathrm{n}$ & 12 & 12 & 12 & 12 & - & 12 \\
$\mathrm{BMR}$ & $\mathrm{r}$ & $-.750^{* *}$ & .301 & $-.618^{*}$ & -.526 & $-.616^{*}$ & - \\
& $\mathrm{p}$ & .005 & .343 & .032 & .079 & .033 & - \\
& $\mathrm{n}$ & 12 & 12 & 12 & 12 & 12 & - \\
\hline
\end{tabular}

Note. Correlation Significance Level $* 0.05,{ }^{* *} 0.01$.

Table 4. Correlation relationships between oxygen consumption capacity and body composition variables of tiny national boxers

\begin{tabular}{llllll}
\hline & & $\left(\mathrm{VO}_{2}\right)_{\max }$ & $\mathrm{FM}$ & $\mathrm{FFM}$ & $\mathrm{BMI}$ \\
\hline$\left(\mathrm{VO}_{2}\right)_{\max }$ & $\mathrm{r}$ & - & $-.696^{*}$ & $-.666^{*}$ & $-.763^{* *}$ \\
& $\mathrm{p}$ & - & .012 & .018 & .004 \\
& $\mathrm{n}$ & - & 12 & 12 & 12 \\
$\mathrm{FM}$ & $\mathrm{r}$ & $-.696^{*}$ & - & .389 & $.937^{* *}$ \\
& $\mathrm{p}$ & .012 & - & .212 & .000 \\
& $\mathrm{n}$ & 12 & - & 12 & 12 \\
$\mathrm{FFM}$ & $\mathrm{r}$ & $-.666^{*}$ & .389 & - & .543 \\
& $\mathrm{p}$ & .018 & .212 & - & .068 \\
& $\mathrm{n}$ & 12 & 12 & - & 12 \\
$\mathrm{BMI}$ & $\mathrm{r}$ & $-.763^{* *}$ & $.937^{* *}$ & .543 & - \\
& $\mathrm{p}$ & .004 & .000 & .068 & - \\
& $\mathrm{n}$ & 12 & 12 & 12 & - \\
\hline
\end{tabular}

Note. Correlation Significance Level *0.05, ${ }^{* *} 0.01$. 


\section{Discussion}

This research was done on the purpose of the investigation of the physical and physiological fitness of tiny national boxers in terms of various performance variables. In this context, the limitation of the researches on tiny national boxing athletes required definitions of some physical and physiological performance data. In the literature, among the studies conducted in the determination of physical and physiological performance data in different age groups, Atan et al. (2013) determined that $\mathrm{VC} \%$ value was found in the best swimmers (174.62), the second was found in wrestlers (137.54) In terms of pulmonary function tests they performed on a total of 350 participants, 50 sedentary athletes and 50 athletes from the branches of judo, athleticism, wrestling, taekwondo, table tennis and swimmimng who actively do sports in stars category in the 15-16 age group, and observed that the athletes have higher value respiratory functions than sedentary athletes (104.02) in both sports branches. When compared with the results of this research, it is seen that it is lower than these results depending on the age range. In another study conducted by reseracher Azad and Zamani (2014), lung function estimating equation was developed in normal $(\mathrm{n}=38$, age ave. $=15.9 \pm 0.86)$ and low weight $(\mathrm{n}=29$, age ave. $=16 \pm 0.84)$ young girls. According to the results of the study, FVCbaz (L) was found to be $2.78 \pm 0.38$ and FVCreference (L) was found to be 3,254 \pm 0.39 in low-weight ones. They found that FVCbase (L) value was $2.88 \pm 0.34$ and FVCreference (L) value was $3.18 \pm 0.36$ in normal weight participants. 9 elite male boxers particioated in Akgül's (2016) study. In the comparison of pretest-posttest values of body compositions, while he found that the post test values of body weight and body mass index were significantly lower than pretest values $(p<0.05)$, he observed no statistically significant difference in the comparison of pretest values and posttest values of basal metabolic rate, fat percentage, lean body mass and total water weight were compared with pre-test values $(\mathrm{P}>0.05)$. Totally 29 boxers from Turkey Big Men's Boxing National Team were participated in another study by Pala and Savuc (2011). All boxers' some physical and biomotoric parameters of height, weight, body composition, vertical jump, hand grip strength and some oxidative stress parameters of Malondialdehyde, 8-isoprostan, 4-hydroxinonenal and 8-hydroxy-2'-deoxyguanosine were examined at the beginning and end of the camp. As a result of the study. They found statistically significant variations in body weight, vertical jump, left hand grip strength and serum 8 -isoprostane values of the athletes $(\mathrm{pg} / \mathrm{ml})$ before and after camp $(\mathrm{P}<0.05)$. Although there was a decrease in malondialdehyde, 8-hydroxy-2'-deoxyguanosine and 4hydroxinonenal values, they did not observe statistical significance $(p>0.05)$. 18 boxers between the ages of 19-25 actively engaged in boxing were participated in the Ozdil's study (2016). In the study; When the findings obtained from the result of application of resistance rubber group, dumbly group and control group performed together with 6-week competition period trainings were examined, he didnot found a statistically significant difference between both in-group and intergroup pretests and posttests of the body weight, anaerobic power and maximal bench parameters values. However, when the pre-test and post-test data of the groups in itself were examined, it has been determined that there was a statistically significant $(\mathrm{p}<0.05)$ increase in anaerobic power levels of all three groups $(\mathrm{LG}, \mathrm{DG}, \mathrm{KG})$. Kilıç (2012), in his study on the age population close to this study, found differences in body composition data, right hand grip strength $(\mathrm{kg})$, vertical jump $(\mathrm{cm})$ and aerobic power $(\mathrm{ml} / \mathrm{kg} / \mathrm{min})$ parameters of the athletes before and after the 8-week training program for 13-14 years old Star Male male twenty-four boxing athletes $(\mathrm{p}<0.01)$. Another researcher, in Savaş and Uğraş (2014) pre-post test analyzes on forty-eight boxing, taekwondo and karate athletes at the end of the eight-week training program, in boxers; body weight, visual reaction time, in the athletes doing taekwondo; body fat percentage, in athletes doing karate: in body weight and anaerobic power values, statistically differences were found at significance level $(\mathrm{p}<0.05)$. In another study, Çınar and et al. (2009) in their research on 26 boxers, the average age (20.77 \pm 1.34$)$, from Turkish and Ukrainian boxing national team, they found statistically significant differences in flexibility value in favor of Turkey, in fat percentage, right hand grip strength, left hand grip strength and sport age values in favor of Ukraine and according to the obtained values, the Ukrainian Boxing National Team athletes had better averages than the Turkish Boxing National Team athletes in the terms of the physical fitness parameters. In another study conducted by Çakmakçı et al. (2005), 11 boxers with an average age of $20.81 \pm 2.35$ years from the Turkish National team, and 9 boxers with an average age of $24.88 \pm 3.14$ years from the National Team of Georgia participated in the study. In their esearch, while no significant difference was found in height, body weight, forced vital capacity, inspiratory and expiratory parameters of Turkey and Georgia National Boxing Teams, at $\mathrm{p}>$ 0.05 level, they found significant difference in age parameter at $\mathrm{p}<0.05$ level. El-Ashker et al. (2018) in their research examined various physiological variables on elite male boxing athletes and amateur boxing athletes with an average age of 21 and as a result they did not observe a significant difference between VO2 max values and VO2 values ( $p>0.05)$. In another study, Aydaş et al. (2002) made comprasions between National Boxing team with the average age of $22 \pm 70$ and the other two competing boxing groups in the terms of various physical and physiological variables; height, weight, body fat percentage, flexibility, resting heart rate, blood pressure, 
hand grip strength and anaerobic power and did not find a significant difference between them ( $p>0.05)$. Güven et al. (2017) had 10-12 years old badminton players done 8-week basic badminton training and reported that there was a positive improvement in the hand grip strength of both the right hand and left hand compared to the pre-test.

Guidetti et al. (2002), eight elite amateur Italian boxing athletes with an average age of $22.3 \pm 1.5$ were ranked according to their grades in international tournaments and world amateur boxing criteria and correlations in the physiological variables of athleteswere examined according to ranking. In the results, the observed that hand grip strength was highly correlated with competition ranking $(\mathrm{p}<0.01)$, however, there was a moderate relationship in the wrist circumference variables of VO2 $(\max )$ and anthropometric data. Another researcher, Ghosh (2010), in his study on six elite boxers with an average age of $21.4 \pm 3.0$ years, investigated the metabolic and physiological responses of special training practices on athletes. He found significant increase in VO2 (max) values of boxers and as a result, in his study, provided evidence that specialized specific training practices in boxing give high responses on cardiovascular and metabolic values. Aktaş (2019) measured the dominant arm and leg isokinetic strengths of elite boxers aged $21.38 \pm 2.39$ and as result, stated that both upper and lower extremities of the boxers were dominant. This result showed that both arm strength and leg strength should be good due to the characteristics of boxing.

\section{Conclusion}

In literature studies, the existing of that the results of physical and physiological fitness of boxers is higher than the results of this study we attribute to difference in age population. In recent studies, the limitations of studies similar to this are striking. This situation necessitates the necessity of research on the tiny national boxers. As a result of the research. The existing of that there were the negatively relationships between the highness of maximal oxygen use capacity and basal metabolic rate and body composition components at relational base show the effectiveness of oxygen use on the protection of basal metabolic rate and body composition at healthy and desired level. This means that the development of oxygen consumption capacity through periodic training practices will achieve the desired physical fitness for athletes in body composition and basal metabolism values. It is thought that the physical and physiological data of the tiny national boxing athletes between 11-13 years of age will contribute to the literature in this age group.

\section{References}

Akgül, M. N. (2016). The effect of 6-week competition period training on body composition in boxers. Doctoral Dissertation, Selçuk University, Institute of Health Sciences. https://doi.org/10.15314/tsed.319374

Aktaş, S. (2019). Examination of Lower-Upper Extremity Power and Force Parameters of Elite Athletes. Doctoral Dissertation, Selçuk University, Institute of Health Sciences, Konya.

Atan, T., Akyol, P., \& Çebi, M. (2013). Comparison of respiratory functions of athletes in the category of stars dealing with individual sports. Dicle Medical Journal, 40(2), 192-198. https://doi.org/10.5798/diclemedj.0921.2013.02.0253

Aydaş, F., Uğraş, A., \& Savaş, S. A. (2012). Comparison of Selected Physical and Physiological Characteristics of National Boxing Team and Competitive Two Different Boxing Teams. Journal of Physical Education and Sport Sciences, 7(2), 11-22.

Azad, A., \& Zamani, A. (2014). Lean Body Mass Can Predict Lung Function in Underweight and Normal Weight Sedentary Female Young Adults. National Research Institute of Tuberculosis and Lung Disease, $13(2), 20-26$

Bozkurt, I. (2010). Analysis of bone mass density of lumbar spine zone of athletes. African Journal of Biotechnology, 9(43), 7361-7371.

Bozkurt, I. (2010a). Effects of exercises on bone mineral density of proximal femur region among athletes in different branches. International Journal of Physical Sciences, 5 (17), 2705-2714.

Bozkurt, I., Pepe, K., Özdemir, M., Özdemir, O., \& Coşkun, A. (2011). Morphometric evaluation of the effect of methenolone enanthate on femoral development in adolescentrats. Scientific Research and Essays, 6(7), 1634-1638.

Çakmakçı, E., Tatlıcı, A., Kahraman, S., Yılmaz, S., Ünsal, B., \&Özkaymakoğlu, C (2019). Does once-a-week boxing training improve strengt hand reaction time? International Journal of Sport Exercise and Training Science, 5(2), 88-92. https://doi.org/10.18826/useeabd.552086

Çakmakçi, E., Tatlici, A., \& Yirmibeş, B. (2018). Comparıson of Some Performance Parameters of Physıcally 
Actıve Mentally Retarded and Inactıve Mentally Retarded Indıvıduals. European Journal of Physical Education and Sport Science.

Çakmakc1, O. (2002). Comparison of Selected Physical Properties of Turkish and Georgian National Boxing Teams. Unpublished Master's Thesis, Konya.

Çakmakcı, O., Fişekçioğlu, İ. B., Çınar, V., Akkus, H., \& Kılıç, M. (2005). Comparison of some respiratory parameters of Turkish and Georgian-A National Boxing Teams. Spormeter Journal of Physical Education and Sport Sciences, III(4), 133-136. https://doi.org/10.1501/Sporm_0000000057

Çınar, V., Biçer, Y., Pala, R., \& Savucu, Y. (2009). Comparison of some physical fitness values of Turkish and Ukrainian national boxing teams. E-Journal of New World Sciences Academy, 4(3), 154-161.

El-Ashker, S.,Chaabene, H., Negra, Y., Prieske, O., \&Granacher, U. (2018). Cardio-Respiratory Endurance Responses Following a Simulated $3 \times 3$ Minutes Amateur Boxing Contest in Elite Level Boxers. Sports, 6(4), 119. https://doi.org/10.3390/sports6040119

Ghosh, A. K. (2010). Heart rate, oxygen consumption and blood lactate responses during specific training in amateur boxing. International Journal of Applied Sports Sciences, 22(1), 1-12. https://doi.org/10.24985/ijass.2010.22.1.1

Guidetti, L., Musulin, A., \& Baldari, C. (2002). Physiological factors in middle weight boxing performance. Journal of Sports Medicine and Physical Fitness, 42(3), 309-314.

Güven, F., İnceler, A., Aktaş, S., Selahattin, K. S., Yılgın, A., \& Yusuf, E. Y. (2017). Effects of badminton training on some physical parameters in badminton players aged 10 to 12 years. Turkish Journal of Sport and Exercise, 19(3), 345-349.

Kalyon, T. (1990). Sports Medicine. Ankara: Gata Printing House.

Karatosun, H. (2003). Physiological Basics of Training. Author's Own Publication.

Kılıç, Y. (2012). The Effect of 8-Week Camping Training on Some Physical Fitness, Physiological and Anthropometric Properties of 13-14 Age Boxers. Published Master's Thesis, Elazığ.

Özdil, G. (2016). The Effect of Strength Training on Maximal Strength and Anaerobic Power in Boxers. Doctoral dissertation, Selcuk University, Institute of Health Sciences.

Özer, K. (2016). Physical Fitness. Ankara: Nobel Publishing.

Özer, Ö., \& Kılınç, F. (2012). Comparison of strength, speed and flexibility performance of elite individual and team athletes. International Journal of Human Sciences, 9(1), 360-371.

Pala, R., \& Savucu, Y. (2011). Investigation of Some Physical and Oxidative Stress Parameters of Boxing National Team During European Championship Preparation Camps. Firat University, Institute of Health Sciences, Department of Physical Education and Sports.

Savaş, S., \& Uğraş, A. (2014). Effects of Eight-Week Pre-Season Training Program on Physical and Physiological Characteristics of Collegian Male Boxing, Taekwondo and Karate Athletes. Gazi University, Journal of the Faculty of Education, 24(3).

Selçuk, M. S. (2014). The Effect of 6-Week Resistance Tyre Practice on Maximal Force and Anaerobic Power in Female Boxers. Doctoral dissertation, Selçuk University, Institute of Health Sciences.

Sevim, Y. (1991). Basketball, Technique - Tactic - Training (1st ed., p. 7). Gazi Office Bookstore, Ankara.

Soslu, R., Guler, M., Ömer, Ö., Devrilmez, M., Cincioğlu, G., Dogan, A. A., \& Esen, H.T. (2018). Effect of Acute Fatigue on Static Balance in Boxers. Sportive, 1(1), 19-30.

Soslu, R., Özer, Ö., \& Çuvalcioğlu, İ. C. (2018). The Effects of Core Training on Basketball Athletes' Antioxidant Capacity. Journal of Educationand Training Studies, 6(11), 128-134. https://doi.org/10.11114/jets.v6i11.3454

Soslu, R., Özer, Ö., Güler, M., \& Doğan, A. A. (2019). Is there any Effect of Core Exercises on Anaerobic Capacity in Female Basketball Players? Journal of Educationand Training Studies, 7(3), 99-105. https://doi.org/10.11114/jets.v7i3.3959

Tamer, K. (2000). Measurement and Evaluation of Physical Physiological Performance in Sports. Ankara: Bağırgan Publishing House.

Tatlıcı, A., Çakmakçı, E., Yılmaz, S., \& Arslan, F. (2018). Comparison of Visual Reaction Values of Elite Deaf 
Wrestlers and Elite Normally Hearing Wrestlers. Turkish Journal of Sport and Exercise, 20(2), $63-66$. https://doi.org/10.15314/tsed.440813

Tatlici, A., \& Cakmakci, O. (2019). The effects of acute dietary nitrate supplementation on anaerobic power of elite boxers. Medicına Dello Sport, 72(2), 225-233.

Tatlici, A., Sercan, Y., \& Samet, A. (2018). Türkiye'de işitme engelliler ve spor. Türkiye Birliği Yayınları, 589598.

Tatlıc1, A., \& Ünlü, G. (2018) Acute Effects of Proprioceptive Neuromuscular Facilitation (Pnf) Applications on Dynamic Balance Performance in Elite Wrestlers. Sportive Perspective: Journal of Sport and Educational Sciences, 57-63.

Tayar, M., \& Korkmaz, N. (2007). Nutrition Healthy Life. Ankara: Nobel The distribution of Publication.

William, B., \& Gene, A. (2013). Exercise Physiology Laboratory Handbook (Kamil. Özer, Trans.). Nobel Publishing.

Williams, L., \& Wilkins. (2013). American College of Sports Medicine (Ed.). ACSM's Health-Related Physical Fitness Assessment Manual.

Zorba, E. (2001). Physical Fitness. Ankara: Bookstore.

Zorba, E. (2014). Lifelong Sports for All. Ankara: Canset Form Printing.

\section{Copyrights}

Copyright for this article is retained by the author, with first publication rights granted to the journal.

This is an open-access article distributed under the terms and conditions of the Creative Commons Attribution license (http://creativecommons.org/licenses/by/4.0/). 